(RESEARCH ARTICLE)

\title{
The imperatives of effective project implementation on national infrastructural development: The engineering perspective
}

\author{
Obi Lawrence $E^{*}$ \\ Department of Civil Engineering, Imo State University Owerri.
}

Publication history: Received on 08 December 2020; revised on 15 December 2020; accepted on 17 December 2020

Article DOI: https://doi.org/10.30574/wjaets.2020.1.2.0033

\begin{abstract}
Project implementation has witnessed multifarious challenges ranging from quackery, corruption, project failures, and inflation of project costs to project abandonment. This has led many developing countries to remain in the doldrums of economic development. An effective project implementation is one that involves all relevant professionals and follows the necessary channels of project execution. The research focused on how effective project implementation can affect the infrastructural development in Nigeria. The research revealed that an effective project implementation will add value to infrastructure development through the elimination of abandonment of projects, projects failure, corruption, project delay and quackery. This paper through its research opined that an effective project implementation will improve the national infrastructural development through durability and high quality infrastructure, increased infrastructural serviceability and sustainability, improved value through transparent project execution, due process compliance and productivity enhancement in construction activities. With the results of the research, it is being recommended that projects should be handled by relevant professionals and the various cycles of civil engineering project be allowed to have its uninterrupted course in project execution.
\end{abstract}

Key words: Infrastructure; Project; Implementation; Imperatives

\section{Introduction}

The post-war years saw Nigeria enjoying a meteoric, oil fuelled economic upturn in the course of which the scope of construction activities of the Nigerian Federal Government grew to an unprecedented degree with increased earnings from oil revenues. This led to a significant boom in the construction industry after the civil war, because of the need for rehabilitation and the reconstruction of war-ravaged infrastructures like buildings, roads, bridges, and dams. Another decision made by Gowon at the height of the oil boom was to have what some considered negative repercussions for the Nigerian economy in later years, although its immediate effects were scarcely noticeable- his indigenization decree of 1972 which declared many sectors of the Nigerian economy off-limits to all foreign investments, while ruling out more than minority participation by foreigners in several other areas. This decree provided windfall gains to several well connected Nigerians but proved highly detrimental to non-oil investments in the Nigeria economy. Nigerians postcivil war national and state peace-building projects were framed around reconciliation, rehabilitation and reconstruction policies which shaped the nature of national citizenship, the peace dividend and re-integration of the Igbos into a united Federal Republic of Nigeria.

Infrastructural development reflects the progress and state of economic success of any given society and infrastructure constitutes a benchmark to measure the level of any country's standard of development. This is due to the fact that the degree of quality and efficiency of any national infrastructural development is true reflection of the society's level of development in different areas which include quality of life, degree of industrialization, educational standard, quality of transportation, economic expansion and growth, health sector standard, business growth, etc. It is an established fact

${ }^{*}$ Corresponding author: Obi Lawrence $\mathrm{E}$

Department of Civil Engineering,Imo State University Owerri.

Copyright (C) 2020 Author(s) retain the copyright of this article. This article is published under the terms of the Creative Commons Attribution Liscense 4.0. 
that all developed nations of the world have highly rated infrastructures which have positioned them to make waves in all areas of life including standard roads, high industrialization level, optimal electrical energy generation, good education and health facility and high value Gross Domestic Product. These developed Nations improved their economies by putting on the speed lane their infrastructure and keeping a continuous programme that stabilizes and adds value to them.

The knitty gritty of the matter is that a country cannot be opulent without adequate infrastructure. Countries that were given accolades for civilization attained that through infrastructure as we can still recall the Egyptian experience. It is arguable that the great civilization attained greatness only through the establishment of adequate and sustainable infrastructure. The World Bank has established that every government funds spent on infrastructures creates an adequate 1\% increase in Gross Domestic Product and invariably depicts that there is a correlation between any meaningful inputs on infrastructure and economic growth. Infrastructure include roads, transportation facilities, electricity establishments, oil and gas facilities, telecommunication, etc.

Project is a temporary endeavour designed to produce unique product or result with a defined beginning and end. With this definition, it is therefore expedient that projects be effectively implemented to achieve the desired end-product and at the same attain sustainability.

\subsection{Infrastructure}

Infrastructure can be defined basically as physical and organizational structures and facilities such as buildings, roads, power supplies, bridges, etc needed for the operation of a society or enterprise. Infrastructure is also the set of fundamental facilities and systems that support the sustainable functionality of households and firms. It normally serves a country, city or other sector in the form of the facilities necessary for the growth of the economy. Infrastructure is the general term for the physical systems of a business, region, or nation. Typically ranges of infrastructure are transportation, communication, sewage, water, and electric systems. These systems are capital intensive and high cost investments which are vital to any nation's economic development [1].

Infrastructure in the transportation system are those facilities that make the movement of people and goods from one to another possible. Infrastructure in the transportation system include railway structures housing the railway station, rail carriage way, roads, parks, airports, seaports, habours etc. The communication system infrastructures aid the transmission of signals between the transmitting systems, and the people. Typical examples of communication system infrastructures are transmitting towers, transmitter, and examples of electrical systems are hydropower stations (or generating stations), transmission and distribution lines and sub-stations, pylons, poles, etc Infrastructure for sewage system are soakaways pits, septic tanks, and that of solid waste are incinerators, landfills, recycling facilities, etc. Water infrastructures are regarded as those facilities that make water available to users in the most suitable and safe form for the various purposes such as domestic use (drinking, washing, and gardening), industrial use and commercial uses. The infrastructures involved in this include dams, weirs, pipes, treatment plants, etc.

Infrastructure is the lifeblood and the essence of continued survival of any nation. Functional infrastructure is essential not only for economic wellbeing of a nation but also for security and political stability as well. Efficient infrastructural facilities enhance rapid economic development thereby raising the standard and security of life. Conventional infrastructure includes public utilities such as power, telecommunications, water supply, sanitation and sewage and waste disposal, public works such as irrigation systems, schools, housing and hospitals, transport sectors such as roads, railways, ports, waterways and airports and research facilities such as laboratories and related equipment. Infrastructure services include provision, operation and maintenance of physical facilities. Engineering projects compared to other investments categories often involve heavy monetary expenditures or high capital injection inputs. Suffice it to say that when an engineering project fails, colossal money has gone down the drain. Inadequate infrastructure can be conspicuously related to the poverty of nations [2].

\subsection{Public-private-partnership (PPP)}

Public-Private-Partnership is an arrangement which involves an understanding between non-governmental organizations and the government on the implementation and prosecution of infrastructural development. Thus the emergence of the PPP as an option and contemporary approach to funding and managing sustainable infrastructural development and its rehabilitation. Ensuring the provision of functional public infrastructure is a fundamental responsibility of the public sector which represents the government of the day. In today's reality, sustaining the financing of infrastructure through general budgetary provisions is no longer feasible. Globally, the alarming cost of inadequate infrastructure, arising from poor performance of state-owned monopolies has necessitated active steps towards competition, private sector entry and foreign investments. This partnership which is deemed to be an 
acceptance agreement has attracted overwhelming welcome as an approach which can help government achieve much infrastructural for the people.

PPP is an arrangement between government and private sector entities for the intention of providing public infrastructure, community facilities, and related services. Such partnership should be characterized by sharing investment, risk, responsibility and reward between partners. Most successful partnership arrangement draws from the strength of both public (government) and private sectors to achieve synergy.

\subsection{Project}

Project can be defined as an activity which has a starting and finishing time with a definite objective and purpose to serve. From the definition, it can be understood that time, cost and performance goals are involved in every project. A project has an important size, value and complexity subjected to time pressure for completion.

The Project Management Body of Knowledge, PMBOK, defines a project as a temporary endeavour undertaken to create a unique product, service or result. This in comparison with the other major group [of cativities carried out by organizations which are routine and repetitive are called operations. In practice, most projects depend on finite or limited resources through which the objectives have to be attained. The essence of projects is to increase the total benefits accruable by the completion of the project. The planning of projects is very significant towards the achievement of its objectives. A project can also be seen as an effort in which human, material and financial resources are organised in a novel way, to undertake a unique scope of work with given specifications within the constraints of cost and time, so as to achieve beneficial change defined by quantitative and qualitative objectives.

The tangible deliverables of a project include project scope which defines what's is to achieved, the project time or duration which defines the time frame in which the project should be completed, the project cost which stipulates the amount within which the project should be achieved, and project quality which maintains that the quality objectives of the project should be met [3].

\subsection{Project management}

Project management can be generally defined as the planning and controlling of all operations geared towards achieving an efficient project. The project management process includes initiating, planning, executing, monitoring and controlling and closing operations which must be taken care of by the project manager. The initiating process involves the authorization of commencement of the project and it is a very critical phase of the project. Poor understanding of the phase and its management may result to taking a wrong step at the early time of the project which results to time wastage and wastage of resources. The planning phase is the most familiar and hitherto defined as the project management proper. This stage is the hub of project management which involves breaking the project into executable tasks, sequencing, and networking the tasks to deliver the project, assigning time and resources to the tasks, and creating an integrated plan to deliver the project. This process needs input from critical stakeholders especially the technical professionals who must not only assign staff and equipment but also determine the duration and interdependence of tasks. The execution phase represents the phase when the project plan is implemented with actual construction or production. The monitoring and control phase usually goes simultaneously with the execution phase. Monitoring and control tools include regular site and off-site meetings, inspection of works, and continuous evaluations of work done. The controlling schedule of a project is complex and involves the constant monitoring of schedule, cost quality, scope and risk. [3]

\section{Effective project implementation}

Engineering projects can be said to be effectively implemented when the necessary steps, processes, skills, materials and the appropriate personnel are involved and the execution carried out in accordance with the laid down standards and specifications. Engineering projects are very expensive and its high capital consumption demands that optimal efforts should be taken to ensure that the value for the capital involved is pursued and made to be an inherent attribute of such projects. The essential virtue of engineering practices expects that any project execution will follow the norms, ethics, standards and specifications as outlined in the engineering code of practice. The effective project implementation from the engineering perspective should strictly adhere to such major criteria as due process; planning, design, supervision, and post project maintenance scheme. The implementation of an engineering project can be summarised in three umbrella words of planning, project execution and post project maintenance. 


\subsection{Due process in contract award}

Due process is the parlance associated with bureau for public procurement and price intelligence(bppi) coined by the nigerian citizenry to portray its acceptance and popularity as an instrument to change the hackneyed old order of greed, dishonesty, impropriety, unethical practices financial recklessness, fictitious projects, poor quality job execution, abandonment of projects, collapsed buildings, poor durability and lack of sustainability tenable on the award and prosecution of project as well as the procurement of services. Prior to the advent of due process, climate for the award and implementation of civil engineering projects. Civil engineering projects executions were characterized by corruption, mutual distrust between contractors/consultants and the financier (i.e government), failed project, shoddy jobs, substandard projects, inflation of contract value/cost, over-invoicing; proliferation of projects. Ghost projects etc. It was against this background that a commission was set-up to assess the level of decay and impropriety in public procurement. This was done in 1999 by the previous administration. The result of the assessment of projects in nigeria was terrifying and alarming. The report revealed that the country lost an average of $\$ 10$ billion annually to corrupt practices in public procurement. There was therefore a grave need for immediate but a more drastic measure to sanitize the procurement transactions and this gave birth to the budget monitoring and price intelligence unit. Following the achievement of the bmpiu under the vivacious and vibrant leadership of obyezekwesili, the bmpiu and her protagonist were nicknamed by nigerians as due process". In the bid to consolidate and sustain the benefits of the due process, a bill was prepared and sent to the national assembly to give it a legislative backing and improve on its structure. The bill was targeted at giving the procurement reform an implementation impetus through a legal framework. It was also meant to set and define standards, principles and procedure for the restoration of transparency, competition and value for money in public procurement through the promotion of a service delivery based on unbiased professionalism, it was also intended to bring nigeria at parity with global standard to instil investor confidence and foster economic growth through innovation, creativity, hardwork and competition. The implementation of the procurement act begins with advertisement of the product in standard national media to crate the awareness among competent vendors, service providers, contractors and consultants. This is to ensure competition from the responses which would come in form of tendering, or intentions to take up the job. The intending companies are subjected to a fair and transparent prequalification exercise with no manipulations and prejudices. This gives rise to the emergence of capable and competent entity from the lot who would then proceed to the next stage. The next stage is the financial and technical bidding which is only open to those who have pre-qualified. The technical bidding is an exercise that assesses and assures the technical/professional competence of the bidders. On the other hand, the financial bidding ascertains the financial muscle of all the companies or contractors. By financial bidding, the financial capability of the prospective contractor and her overall financial standing are known. The technical and financial bidding is very crucial as it determines which of the bidders have the best potential to win the contract, although this will be based on the lowest responsive bid judged on the framework of processes being considered. The most delightful ingredient of the procurement act that made it an imperative and a sinas qua non for the contract practice in civil engineering projects, is the most procurement audit of careful supervision which may lead to prosecution in case of infringement on the tenets of the contract terms. The bureau is empowered to debar any supplier, contractor or service provider that contravenes any provision of the act and its regulation. This implies that contractors will be more careful to observe all terms of the contract specifications, standards and avoid shoddy jobs to avoid being blacklisted. The bureau has powers to cancel any procurement process if in her observation it was not fair and open. In her provision all procurements should contain warranties for the durability of goods and this compels the contractor to use prerequisite skills in service provision and also use of genuine materials and inputs in job execution. The bureau is also saddled with the responsibility of harmonizing the existing government, policies and practices by regulating, setting, standards, and developing the legal framework and professional capability for public procurement in Nigeria [4].

Due process in contract award is a proactive effort of legality geared towards ensuring that enough and solid arrangement which defines the roles and responsibilities of the parties involved in the engineering. This clears out the doubts and uncertainties envisaged in the project implementation.

\subsection{Contract practice}

Webster's comprehensive dictionary encyclopaedic edition defined contract "as an arrangement or settlement by agreement entered upon with reciprocal obligations". Contract involves a bargain by two or more parties in which each of the parties has a defined role to play for mutual benefit. The agreement could be written or oral. The expression of intentions by the parties to enter into an agreement or contract is not enough due to complexities of projects especially civil engineering project. It becomes obvious therefore that, to create a legally effective contract, there must a written agreement which constitutes the "contract". The necessity of the definition of terms is hinged on a possible infringement of the stipulations of the contract by any of the parties and the expected consequence of arbitration. Agreement stipulations which constitute the contract has the attribute of any enforceable, at any competent law court. This means that the contract will have such content as offeror, offeree, consideration, and form. The offeror means the party or 
entity making the offer while the offeree is the party accepting the offer. Consideration stands for the return which may be pecuniary or otherwise promised by any of the parties to another. The consent of any the parties must be authentic and not to be secured through duress, error, undue influence, misrepresentation or fraud. The contractor should have a legal subject matter and must be legally binding on all the parties involved. A contractor must have a provision for claim of damages which could in form of money or service. Contracts take various forms and these forms or types are determined by natural parties involved, pecuniary consideration, quantity of works etc [4].

\subsection{Project planning}

Engineering projects are planned and this involves the collection of data for the project. The project planning includes reconnaissance, feasibility studies and some other preconstruction activities such as design and cost-estimation. This stage of the project is continuous although it depends on the level of intensity and technical details. Engineering data are collected and subjected to analysis. These are gotten through relevant tests, typical examples of such tests include soil, hydrology, hydraulic, surveying, mapping, geotechnical, etc.

\subsubsection{Reconnaissance}

A reconnaissance study is conducted to determine whether or not the project has an acceptability to local interest and whether there is a federal interest and if so whether planning should proceed to the feasibility phase. During reconnaissance, engineering assessments of alternatives are made to determine if they will function safely, reliably efficiently and economically. Each alternative should be evaluated to determine if it is practical to construct operate and maintain. Several sites should be evaluated and preliminary designs can be prepared for each site [7].

\subsubsection{Feasibility phase}

A feasibility study is conducted to investigate and recommend possibilities for the project based on technical evaluation of alternatives and includes a baseline cost estimate and a design/construction schedule. The marketability of the project after construction should also be evaluated. At this stage of feasibility studies, the safety requirements should be articulated. Adequate engineering data must be obtained and analysed with sufficient design to define the appropriate risk associated with the contingencies assigned to reach cost item in the estimate.

\subsubsection{Preconstruction engineering and design phase}

During the pre-construction engineering and design phase, administrative review of the project feasibility is necessary. For a complex project, results of the engineering studies for the individual features of the project must be obtained and submitted and this constitutes to the project design. This allows for sufficient details in the preparation of plans and specifications. The preparation of plans and specifications will aid in the specific designs, materials and their sources, equipment, choice of personnel and construction plant locations. At this stage the Bill of Engineering Measurement and Evaluation (BEME) is developed and this stands as the cost estimate for the project [8].

\subsection{Construction phase}

This is also known as the execution or implementation stage. This phase includes preparations of plans and specifications for subsequent construction contracts, review of selected construction contracts, site visits, support for claims and modifications, development of operation and maintenance manuals. Site visits should be made to ensure and verify that the conditions match the assumptions used to design the civil engineering project features. The personnel should be briefed on the construction process by the project engineer. This phase requires the services of licensed engineers as against quacks. At this phase, all efforts should be harnessed towards construction service delivery which will be in tune with the plans, designs and specifications

\subsection{Operation and maintenance}

This stage is the post-project phase when the project is operated, repaired and rehabilitated by either the project owner or the contractor. The role of this stage is determined by the contract documentation and responsibilities assigned to members at the preconstruction stage of the project. In some projects, the contractor is liable to the maintenance of the project within a given period commonly called the liability period and a certain amount of the contract sum is not paid (which is normally $10 \%$ of the contract sum) for the completion of the project and the amount withheld is called the retention fee. This retention fee is paid back to the contractor at the expiration of the liability period. In case, there is a maintenance within the liability period, the retention fee is used to prosecute the maintenance [9].

When the project is not private public partnership, the operation of the project is normally carried out by the sponsor (owner) of the project or his proxies. This stage includes the periodic inspection of the project which is used to assess 
and evaluate the performance and safety of the project during its lifetime. Modification of the project features which occurs at this operating life of the project should be reflected in the as-built drawings.

These phases of an engineering project namely reconnaissance, feasibility, preconstruction engineering and design, construction and operation and maintenance are known as project cycle of a civil engineering project.

\section{Expediencies of project implementation on national development}

According to zenith economic quarterly empirical survey, inadequate supply of infrastructure was identified as the biggest problematic factor for doing business in nigeria. The same chart equally clearly indicated that poor execution and implementation of projects arising from corruption is responsible for the poor state of the nation's infrastructural development. Infrastructure is a major carrier and driver of health delivery, educational development, transportation, investment, industrialization, and productive employment. These major sectors are the indices which are used to classify the state of any national economy and development.

\subsection{Durability and quality infrastructure}

The outcome of effectively implemented project is durability and quality infrastructure. A project that is properly supervised by engineers within the limits of the plans and specifications will definitely yield durable and high quality projects. When the projects are sound and durable they will have the capacity to boost national development. When such infrastructures as roads and buildings are built to satisfy their lifespans, this will save much money and encourage further investment in other areas of the economy. Sustainability of infrastructure is key to national economic development which can only be achieved through projects that went through the life cycles of projects. Effective project implementation curbs poor project quality arising from poor supervision, poor design, and the use of sub-standard materials.

\subsection{Serviceability and sustainability}

It is only well implemented and constructed projects that can operate and provide service optimally. When project is constructed with the appropriate personnel and quality materials, it gives the needed services and becomes dynamically viable. A well implemented project possesses the required inherent characteristics and strength to render uninterrupted service that can be sustained for allowable period of time. Poorly executed projects at times do not function and when they do, it is often below standard. Apart from serviceability, there is the advantage of reducing abandoned projects, and collapse of structures and this guarantees sustainability.

\subsection{Improved value through transparent project execution}

Professional project implementation is targeted at improving the value of the project through transparency in project execution. This is done by carrying out the construction with the right materials and purchasing materials with transparency. Project management has the improvement of project value as its major concern. A sound project implementation creates values of satisfaction through organizational alignment, consistent use of good practices, better results of processes, better economic outcomes and realization of tangible and intangible benefits. Projects executed by professional have quality management and are completed on record time. The feeling of control that comes from professional project implementation processes is highly great and this reduces overhead cost with less time needed/wasted. A key benefit for a professionally managed and executed project is the ability to deliver the project within the budget cost and time. All control processes of construction activities should be put under check to achieve cost containment.

\subsection{Productivity enhancement in construction activities}

An organised and professional articulated/executed project helps to run tasks in parallel, analyse dependencies, estimate construction activity durations and continuously track the projects critical activities. It is very important to perform a deep assessment of the construction activities through their contents and drive them into completion speedily thereby reducing the time to market. This improves and enhances productivity and consequently the Gross Domestic Product rate (GDP) is highly and positively affected. This represents a direct link to the improvement of the performance of organizations. Projects should have the capacity to achieve a certain rate of return on investment and attract more revenue while costing less. A successful project management controls the flow of a project and keeps the construction team members focused and working within the original scope of the work. 


\section{Conclusion}

Infrastructural development is a key to national economic development. Inadequate project planning and quackery have been considered as significant factors that inhibited infrastructural development in every nation. Professional execution of project is akin to effective project implementation and management and this has proved to be an essential tool for national development. The principal criteria for the project monitoring and control is to track the project plan and its implementation. The impacts and imperatives of effective project implementation to national infrastructural development cannot be overemphasized. Infrastructural development is a major index for economic development and it controls other sectors of national development such as health delivery, transportation, education, industrialization etc. Infrastructural development has its role to play in wealth creation, employment generation and poverty reduction.

A project can be said to be effectively implemented when the project follows the normal channels of project management and the project is controlled and executed by the relevant trained professional and personnel. An effectively implemented project adds immense value to infrastructural development as it ensures sustainability and due process compliance.

\section{Compliance with ethical standards}

\section{Acknowledgments}

My thanks go to civil engineering professionals who were interviewed in the course of this work. I appreciate my wife and children who gave me all the required assistances, I also thank my colleagues in the Department of Civil Engineering, Imo State University, Owerri for their encouragement.

\section{References}

[1] Nurudeen R. 2008 Sustainable Growth in Infrastructure Development: Nigerian Engineering Practice \& PPP, COREN Conference.

[2] Adeola, B 2008, Achieving Value through Effective Project Management, Council for Regulation of Engineering Conference in Nigeria.

[3] Onuoha G 2018, Memory, Reconciliation and Peace building in Post-Civil War South-eastern Nigeria, Princeton University.

[4] Obi L. E. Due Process: Imperative for Contract Practice In Civil Engineering Projects, Journal of Social Policy and Society,2009; vol.4,No. 1

[5] Stephen O. et.al Improving Contract Planning Practice in the Nigerian Construction Industry, The Nigerian Engineering - The Journal of the Nigerian Society of Engineers.1990; Vol. 25 No 4.

[6] Tumer J.R \& Muller, R. 2003. The nature of Project as a Temporary Organization International Journal of Project Management

[7] Ugwu 0.0 \&Agunwamba. J.C. 2011, Civil Engineering Practice and Entrepreneurship, Detroit Innovation, Enugu

[8] en.m.wikipedia.org/wiki-yakubu

[9] www.aboutcivil.org/project-mana 